\title{
Comparisons of National Radium Standards
}

\author{
T. P. Loftus, W. B. Mann, L. F. Paolella, L. L. Stockmann, and W. J. Youden
}

\begin{abstract}
The national primary radium standards of the Federal Republic of Germany and the Dominion of Canada have recently been compared with the two United States national primary radium standards at the National Bureau of Standards. The comparisons were made using the standard electroscope and radiation balance, and the results obtained for these four Hönigschmid standards have been compared with those obtained in an earlier comparison of the United States primary radium standards with that of the United Kingdom, which is also a Hönigschmid standard. In every case, agreement with Hönigschmid's values to within 0.2 percent has been obtained.
\end{abstract}

\section{Introduction}

During January and February 1954 the British primary radium standard and the Canadian national radium standard were compared with the United States primary radium standards at the National Bureau of Standards $[1,2] .{ }^{1}$ The British and United States standards were Hönigschmid standards, whereas the Canadian standard consisted of radium chloride sealed in a glass tube of considerably smaller dimensions than those of the Hönigschmid standards and therefore considerably more closely packed [1]. In any gamma-ray comparison between this Canadian standard and a Hönigschmid standard, it is therefore necessary to apply corrections for selfabsorption of the source [3]. In 1955 the National Research Council of Canada procured a Hönigschmid standard (No. 5425), to replace the older preparation, as the primary radium standard of Canada [4]. This new Hönigschmid standard was compared during the summer of 1955 with the German (No. 5426) and British (No. 5432) Hönigschmid standards in Braunschweig and Teddington, respectively, and was then brought, in early December 1955 , to Washington, D. C., for comparison with the United States Hönigschmid standards (Nos. 5437 and 5440) at the Bureau.

In November 1955 the Hönigschmid standard of the Physikalisch-Technische Bundesanstalt was also compared with the two United States standards.

The results of the measurements carried out on the Canadian, German, and United States Hönigschmid standards are given in this paper, together with a reassessment of the measurements previously carried out at the Bureau on the British and United States Hönigschmid standards $[1,2]$.

\section{Methods of Measurement}

For the comparisons of the Canadian and the German standards with the United States standards, only the NBS standard electroscope [5] and Peltiereffect microcalorimeter, or radiation balance $[6,7]$, were used. These have already been demonstrated to give precise and reproducible results and consequently the counting methods, previously utilized [1], were not again employed to supplement the measurements of the electroscope and microcalorimeter. The procedures of the earlier comparison for

\footnotetext{
1 Figures in brackets indicate the literature references at the end of this paper.
}

both these methods have already been fully described [1] and were again followed precisely.

A new and very careful determination of the thermoelectric power $(d E / d T)$ of the Peltier couples of the radiation balance was carried out, using a pair of copper-sheathed heating and compensating resistance coils whose difference in resistance was precisely measured. The results of a great many measurements gave a new average value at $25^{\circ} \mathrm{C}$ of $d E / d T$ equal to $58.71 \mu \mathrm{v} / \mathrm{deg}$, as compared with $58.78 \mu \mathrm{v} / \mathrm{deg}$ used in the earlier work [2]. This new value will not affect the ratios of the standards as then determined, but will give a different value for the absolute rates of energy emission for the different radium standards. For the purpose of comparison with the results obtained in the Canadian and German intercomparison, those for the British intercomparison have therefore
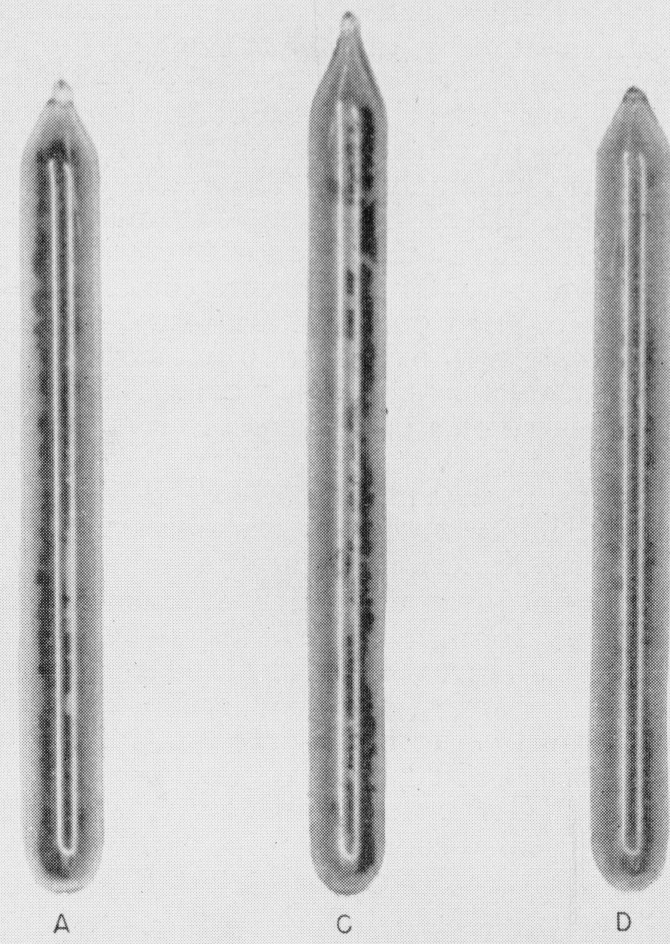

D

FIGURE 1. Three Hönigschmid national radium standards with the grains of salt distributed along the length of the tubes.

$A$, American; $C$ Canadian $D$. American. 
TABLE 1.-Masses of five Hönigschmid radium standards, in Hönigschmid milligrams

\begin{tabular}{|c|c|c|c|c|c|}
\hline & $\begin{array}{c}A \\
\text { U. S. } \\
\text { primary } \\
\text { radium } \\
\text { standard } \\
(5437, \text { XIV })\end{array}$ & $\begin{array}{c}B \\
\text { British } \\
\text { primary } \\
\text { radium } \\
\text { standard } \\
(5432)\end{array}$ & $\begin{array}{c}C \\
C \\
\text { Canadian } \\
\text { primary } \\
\text { radium } \\
\text { standard } \\
(5425)\end{array}$ & $\begin{array}{c}D \\
\mathrm{U} . \mathrm{S} . \\
\text { primary } \\
\text { radium } \\
\text { standard } \\
(5440, \mathrm{XV})\end{array}$ & $\begin{array}{c}G \\
\text { German } \\
\text { primary } \\
\text { radium } \\
\text { standard } \\
(5426)\end{array}$ \\
\hline Mass of radium chloride as determined by Hönigschmid on June $2,1934^{\text {a }}$ & \multirow[t]{2}{*}{50.22} & \multirow[t]{2}{*}{20.50} & \multirow[t]{2}{*}{31.73} & \multirow[t]{2}{*}{26.86} & \multirow[t]{2}{*}{19.19} \\
\hline Radium content, as of June 1934, as given by: & & & & & \\
\hline 1. Hönigschmid's weighings a & \multirow{2}{*}{$\begin{array}{l}38.23 \\
38.12\end{array}$} & \multirow[t]{2}{*}{15.60} & \multirow[t]{2}{*}{24.15} & \multirow{2}{*}{$\begin{array}{l}20.45 \\
20.37\end{array}$} & \multirow[t]{2}{*}{ 14. 61} \\
\hline 2. By comparison with Paris and Vienna 1911 standards ${ }^{b} \ldots$ & & & & & \\
\hline
\end{tabular}

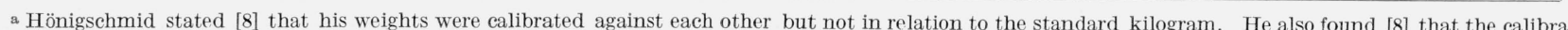

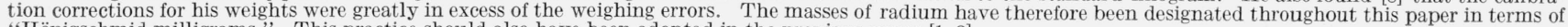
"Hönigschmid milligrams." This practice should also have been adopted in the previous paper [1,2].

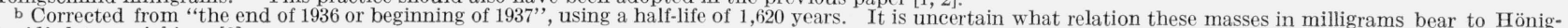
schmid's later weighings [8].

been recalculated. Values for the rates of energy emission for all five standards (British, Canadian, German, and both United States) have also been corrected back to their date of sealing by Hönigschmid, namely, June 2, 1934, in order to eliminate the correction for the decay of radium and the considerably larger correction for the growth of radium $\mathrm{E}$ and polonium-210 between February 1954, when the British intercomparison was carried out, and November and December 1955, when the German and Canadian standards, respectively, were intercompared with the United States standards. In the recalculation of the British results the best estimates have been derived, incorporating the results obtained for the old Canadian standard.

In addition, the sensitivity of the radiation balance has been increased by a factor of some 6.7 , to give a scale deflection of $2.8 \mathrm{~mm} / \mu \mathrm{w}$ instead of $0.42 \mathrm{~mm} / \mu \mathrm{w}$. This was done primarily to calibrate a preparation of some 4.8 curies of tritium in the preparation of the Bureau's tritium standard. The radiation balance has also been placed in a temperature-attenuating enclosure to minimize the effects of fluctuations in the room temperature. This enclosure consists of a box of about $3 / 4$-in.-thick dural, with internal dimensions of approximately 10 by 10 by $10 \mathrm{in}$., surrounded by about a 2 -in. thickness of balsa wood. The radiation balance is placed on a balsa-wood block in the middle of this enclosure. A small opening in the top surface of the enclosure provides for access to the balance. An over-all improvement in the operating characteristics of the radiation balance was obtained.

In the subsequent discussion of the results, the United States Hönigschmid standards will again be designated $A$ and $D$, the British standard $B$, the new Canadian standard $C$, and the German standard $G$. A summary of their essential data is given in table 1, and the two United States standards with the Canadian and German standards are shown in figures 1 and 2 . The tubes containing each of the four standards are of Thüringen glass of $3-\mathrm{mm}$ internal diameter and $0.27-\mathrm{mm}$ wall thickness, and their lengths vary from 36 to $40 \mathrm{~mm}^{2}$

\footnotetext{
${ }^{2} A$ was described as $36 \mathrm{~mm}$ long and $D$ as $37 \mathrm{~mm}$ long in table 1 of the earlier paper [1], and they are indeed thus described in the certificates issued by the paper [1], and they are indeed thus described in the certificates issued hy the International Radium Standards Commission. Measurement of the photo$36.7 \mathrm{~mm}$ long, whereas $D$ is only some $36.3 \mathrm{~mm}$ in length.
}

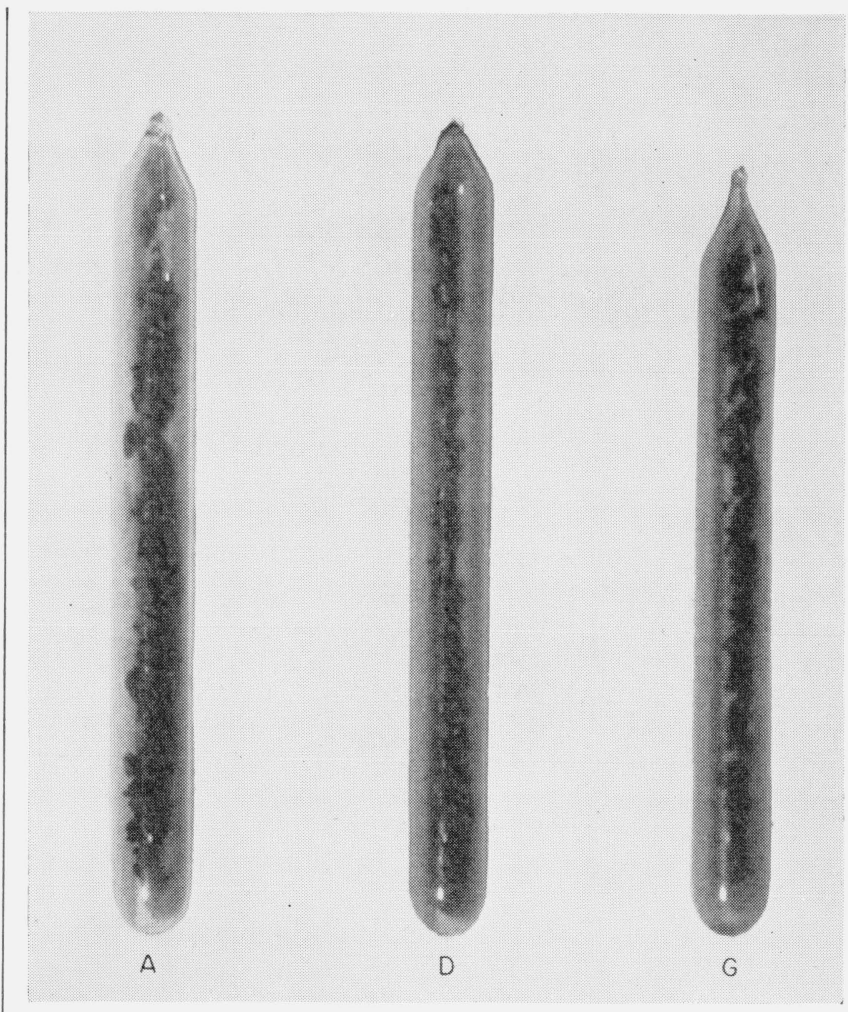

FIgURE 2. Three Hönigschmid national radium standards, with the grains of salt distributed along the length of the tubes.

$A$, American; $D$, American; $G$, German.

\section{Results}

In table 2 are summarized the results of all the measurements of energy-absorption rates for all five standards, both singly and balanced in pairs, at the different times of measurement, uncorrected for either the decay of radium or the growth of its daughter products.

The best estimates of the rates of energy absorption for $A, B, C, D$, and $G$, derived by the method previously described [2], are given in table 3, together with the values of these rates of energy absorption corrected to June 2,1934 . Two additional values of $A$ 
TABLE 2. Rate of energy absorption, in microwatts

\begin{tabular}{|c|c|c|c|c|}
\hline Date & Source & $\begin{array}{c}\text { Energy } \\
\text { absorbed }\end{array}$ & Source & $\begin{array}{c}\text { Energy } \\
\text { absorbed }\end{array}$ \\
\hline $\begin{array}{l}\text { February } 1954 \\
\text { Do } \\
\text { Do }\end{array}$ & $\begin{array}{l}A \\
B \\
D\end{array}$ & $\begin{array}{l}6271.0 \\
2566.3 \\
3364.2\end{array}$ & $\begin{array}{l}A-D \\
A-B \\
D-B\end{array}$ & $\begin{array}{r}2930.9 \\
3721.2 \\
786.5\end{array}$ \\
\hline $\begin{array}{l}\text { November } 1955 \\
\text { Do } \\
\text { Do }\end{array}$ & $\begin{array}{l}A \\
G \\
D\end{array}$ & $\begin{array}{l}6294.4 \\
2416.6 \\
3368.5\end{array}$ & $\begin{array}{l}A-D \\
A-G \\
D-G\end{array}$ & $\begin{array}{r}2925.3 \\
3895.1 \\
956.8\end{array}$ \\
\hline $\begin{array}{l}\text { December } 1955 \\
\text { Do } \\
\text { Do }\end{array}$ & $\begin{array}{l}A \\
C \\
D\end{array}$ & $\begin{array}{l}6295.7 \\
3981.2 \\
3362.2\end{array}$ & $\begin{array}{l}A-D \\
A-C \\
C-D\end{array}$ & $\begin{array}{r}2942.8 \\
2323.6 \\
619.7\end{array}$ \\
\hline
\end{tabular}

TABLE 3. Best estimates of rates of energy absorption, in microwatts

\begin{tabular}{|c|c|c|c|}
\hline Date & Source & $\begin{array}{c}\text { Energy } \\
\text { absorbed }\end{array}$ & $\begin{array}{c}\text { Energy } \\
\text { absorbed } \\
\text { as of June } \\
2,1934\end{array}$ \\
\hline $\begin{array}{c}\text { February } 1954 \ldots \\
\text { Do } \\
\text { Do }\end{array}$ & $\begin{array}{l}A \\
B \\
D\end{array}$ & $\begin{array}{l}6280.6 \\
2563.8 \\
3353.0\end{array}$ & $\begin{array}{l}5747.5 \\
2346.2 \\
3067.7\end{array}$ \\
\hline $\begin{array}{l}\text { November } 1955 \\
\text { Do } \\
\text { Do }\end{array}$ & $\begin{array}{l}A \\
G \\
D\end{array}$ & $\begin{array}{l}\text { 6298. } 6 \\
2411.1 \\
3369.9\end{array}$ & $\begin{array}{l}5729.3 \\
2193.6 \\
3065.4\end{array}$ \\
\hline $\begin{array}{l}\text { December } 1955 \\
\text { Do } \\
\text { Do }\end{array}$ & $\begin{array}{l}A \\
C \\
D\end{array}$ & $\begin{array}{l}6300.3 \\
3979.1 \\
3359.7\end{array}$ & $\begin{array}{l}5731.0 \\
3619.4 \\
3055.1\end{array}$ \\
\hline $\begin{array}{c}\text { December } 1955 \\
\text { February } 1956 \\
\text { Do }\end{array}$ & $\begin{array}{l}A \\
A \\
D\end{array}$ & $\begin{array}{l}\text { 6304. } 1 \\
\text { 6304. } 4 \\
3364.7\end{array}$ & $\begin{array}{l}5734.9 \\
5730.8 \\
3057.8\end{array}$ \\
\hline
\end{tabular}

and one additional value for $D$, obtained in the course of calibrating two other radium preparations for use at the Bureau, are also included.

In the comparisons carried out with the NBS standard electroscope, the method of adjustment of the ratios previously described [2] was again used. The results for the adjusted ratios obtained by the electroscope and also for the ratios obtained from the best estimates of the rates of energy absorption given by the radiation balance are summarized in table 4 , together with the corresponding ratios obtained from. Hönigschmid's weighings. Slight differences in the last figure from the ratios previously reported [1] are due mainly to the rounding off of the last figure in the calculations and are insignificant. In table 4 it will be noted that the electroscope ratios are almost always lower than those obtained by the radiation balance by an amount varying from about 0.1 to 0.4 percent. This would, however, be consistent with a slight gamma-ray source-self-absorption in the larger standard, which, in the ratios given, always appears in the numerator.

For complete internal consistency the ratios shown in columns 3,4 , and 5 of table 4 should be the same for any given pair of standards, apart from the effect of gamma-ray source-self-absorption just noted. It is interesting therefore to compare the percentage or fractional divergencies of these ratios one from another. This can best be done by dividing. one ratio into another, whereupon any systematic error should immediately become apparent. The results of such a comparison are shown in columns 6,7 , and 8 of table 4 , and the effect of gamma-ray source-self-absorption immediately becomes apparent from column 6 by the systematic trend of 2 or 3 parts in a thousand (except in the case of the ratio of $C$ to $D$, which are of nearly the same mass).

Column 7 shows the divergence of the radiationbalance ratios relative to Hönigschmid-weighing ratios to be fairly random. Neither of these methods of measurement involves any gamma-ray effect.

Once again, however, a systematic trend of 3 or 4 parts in a thousand is apparent in column 8. This is consistent with the effect of gamma-ray sourceself-absorption decreasing the electroscope readings for the larger standards. Here again the ratios for $C$ to $D$ would be expected to be higher due to their near equality in mass.

These trends are only slightly significantly greater, however, than the experimental errors involved, but a comparison of the figures of columns 7 and 8 does tend to confirm that the radiation balance is more nearly measuring the ratios as determined by Hönigschmid's own weighings.

As in the earlier intercomparison of the United States and British radium standards [1], it is of interest to compare the radioactive effect per milligram of radium element for each of the standards in order to check the combined internal precision of the electroscope or radiation-balance results, on the one hand, and of Hönigschmid's weighings, on the other.

TABLE 4. Adjusted ratios for five international radium standards

\begin{tabular}{|c|c|c|c|c|c|c|c|}
\hline Date & Standards & Electroscope & $\begin{array}{c}\text { Radiation } \\
\text { balance }\end{array}$ & Hönigschmid & $\begin{array}{l}\text { Ratio of radi- } \\
\text { ation balance } \\
\text { ratio to elec- } \\
\text { troscope ratio }\end{array}$ & $\begin{array}{l}\text { Ratio of radi- } \\
\text { ation balance } \\
\text { ratio to Hö- } \\
\text { nigschmid } \\
\text { ratio }\end{array}$ & $\begin{array}{l}\text { Ratio of elec- } \\
\text { troscope ratio } \\
\text { to Hönig- } \\
\text { schmid ratio }\end{array}$ \\
\hline $\begin{array}{l}\text { February } 1954 \\
\text { Do } \\
\text { Do }\end{array}$ & $\begin{array}{l}A / B \\
A / D \\
D / B\end{array}$ & $\begin{array}{l}2.441 \\
1.870 \\
1.305\end{array}$ & $\begin{array}{l}\text { 2. } 450 \\
\text { 1. } 873 \\
\text { 1. } 308\end{array}$ & $\begin{array}{l}2.450 \\
1.870 \\
1.310\end{array}$ & $\begin{array}{l}1.003 \\
1.002\end{array}$ & $\begin{array}{l}1.000 \\
0.998\end{array}$ & $\begin{array}{l}0.997 \\
-.996\end{array}$ \\
\hline $\begin{array}{l}\text { November } 1955 \\
\text { Do } \\
\text { Do }\end{array}$ & $\begin{array}{l}A / G \\
A / D \\
D / G\end{array}$ & $\begin{array}{l}\text { 2. } 608 \\
\text { 1. } 870 \\
\text { 1. } 395\end{array}$ & $\begin{array}{l}\text { 2. } 612 \\
\text { 1. } 869 \\
\text { 1. } 398\end{array}$ & $\begin{array}{l}2.617 \\
1.870 \\
1.400\end{array}$ & $\begin{array}{l}1.002 \\
1.002\end{array}$ & $\begin{array}{r}.998 \\
-.999\end{array}$ & $\begin{array}{r}.996 \\
-.996\end{array}$ \\
\hline $\begin{array}{l}\text { December } 1955 \\
\text { Do } \\
\text { Do }\end{array}$ & $\begin{array}{l}A / C \\
A / D \\
C / D\end{array}$ & $\begin{array}{l}\text { 1. } 578 \\
\text { 1. } 870 \\
\text { 1. } 185\end{array}$ & $\begin{array}{l}\text { 1. } 583 \\
\text { 1. } 875 \\
\text { 1. } 184\end{array}$ & $\begin{array}{l}1.583 \\
1.870 \\
1.181\end{array}$ & $\begin{array}{l}1.003 \\
1.000\end{array}$ & $\begin{array}{l}1.000 \\
1.003\end{array}$ & $\begin{aligned} .997 \\
1.003\end{aligned}$ \\
\hline February 1956 & $A / D$ & -...- & 1. 874 & 1.870 & -.... & $-\ldots$. & -.... \\
\hline A verage... & $A / D$ & 1.870 & 1. 873 & 1.870 & a 1.002 & a 1.002 & a 1.000 \\
\hline
\end{tabular}


The results of such an internal precision check are given in tables 5, 6, and 7 , for the electroscope and for the radiation-balance measurements. As before, the radioactive effect per Hönigschmid milligram, namely, divisions per second for the electroscope and microwatts for the radiation balance, has been normalized to make the "best average" in each case equal to 100.00 . This best average has again been determined by dividing the sum of Hönigschmid's masses into the sum of the radioactive effects for each series of three standards.

In table 8 are shown the values for $B, C$, and $G$ that are obtained by assuming Hönigschmid's values for $A$ and $D$ and multiplying by the appropriate adjusted ratios, the values for which are given in table 4 . In table 4 the results have been rounded off to four significant figures.

TABLE 5. Radioactive effect per Hönigschmid milligram of radium element, normalized to make the best average equal to 100.00

British intercomparison, February 1954

\begin{tabular}{|c|c|c|c|c|c|}
\hline Method & $A$ & $B$ & $D$ & $\begin{array}{c}\text { Best } \\
\text { average }\end{array}$ & $\begin{array}{l}\text { Standard } \\
\text { deviation } \\
\text { ( } 2 \text { degrees } \\
\text { of freedom) }\end{array}$ \\
\hline Electroscope_. & 99.93 & 100. 31 & 99.88 & 100. 00 & 0.24 \\
\hline Radiation balance & 100.05 & 100.08 & 99.85 & 100.00 & .13 \\
\hline
\end{tabular}

TABLE 6. Radioactive effect per Hönigschmid milligram of radium element, normalized to make the best average equal to 100.00

German intercomparison, November 1955

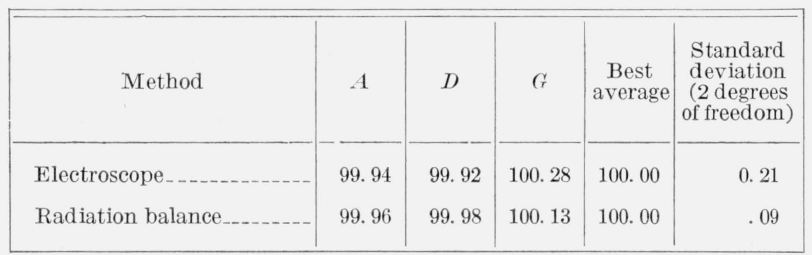

TABLE 7. Radioactive effect per Hönigschmid milligram of radium element, normalized to make the best average equal to 100.00

Canadian intercomparison, December 1955

\begin{tabular}{|c|r|r|r|r|r|}
\hline \hline Method & $A$ & $C$ & $D$ & $\begin{array}{c}\text { Best } \\
\text { average }\end{array}$ & $\begin{array}{c}\text { Standard } \\
\text { deviation } \\
\text { (2 degrees } \\
\text { of freedom) }\end{array}$ \\
\hline Electroscope_-_-_--- & 99.92 & 100.22 & 99.90 & 100.00 & 0.18 \\
Radiation balance_-_-_-_- & 100.08 & 100.06 & 99.72 & 100.00 & .21 \\
\hline
\end{tabular}

TABLE 8. Values of $B, C$, and $G$, in Hönigschmid milligrams of radium element as of June 2, 1934, derived from $A$ and $D$ by means of radiation-balance and electroscope measurements

\begin{tabular}{|c|c|c|c|c|c|}
\hline \multirow{2}{*}{ Standard } & \multicolumn{2}{|c|}{$\begin{array}{l}\text { Radiation balance } \\
\text { through- }\end{array}$} & \multicolumn{2}{|c|}{ Electroscope through- } & \multirow{2}{*}{$\begin{array}{l}\text { Average } \\
\text { all values }\end{array}$} \\
\hline & $A$ & $D$ & $A$ & $D$ & \\
\hline$B$ & 15. $60_{6}$ & 15.637 & $15.65_{8}$ & 15. $66_{7}$ & 15. $64_{2}$ \\
\hline$C_{-}$ & $24.14_{5}$ & 24. $22_{0}$ & 24. $22_{5}$ & $24.22_{8}$ & $24.20_{4}$ \\
\hline$G_{\ldots} \ldots$ & 14. $63_{4}$ & 14. $63_{2}$ & 14. $66_{1}$ & 14. $66_{4}$ & $14.64_{8}$ \\
\hline
\end{tabular}

\section{Discussion of Results}

\subsection{Radiation-Balance Measurements}

The radiation balance permits measurements for each standard separately or for a comparison of any pair of standards. The practice followed in these experiments has, as previously, been that of measuring each standard separately and of making all possible comparisons. There are $n(n-1) / 2$ possible pairs that can be formed from $n$ standards. These $n(n-1) / 2$ measurements, together with the $n$ measurements on the standards alone, give a total of $n(n+1) / 2$ observations for the estimation of $n$ quantities. Section 3 in the preceding study [2] lists the formulas from which the least-squares estimates for values of the radium standards have been derived. These estimates are the so-called "adjusted values," which have been used in all subsequent numerical calculations.

The differences between the adjusted values and the original observations provide an estimate of the standard deviation of the measurements. Table 9 shows a recalculation for the comparison of the United States standards with the British standard and the old Canadian standard. The calculations are also shown for the comparison with the German standard and with the new Canadian standard. The three estimates for the standard deviation of a single measurement are $7.2,6.4$, and $3.8 \mu \mathrm{w}$ and are in

TABLE 9. Calculation of standard deviation, in microwatts, for each comparison of the national radium standards

\begin{tabular}{|c|c|c|c|c|c|}
\hline Standard a & Observed & Adjusted & Difference & \multicolumn{2}{|c|}{ (Difference) ${ }^{2}$} \\
\hline $\begin{array}{c}\mathrm{A} \\
\mathrm{B} \\
\mathrm{C}^{*} \\
\mathrm{D} \\
\mathrm{A}-\mathrm{B} \\
\mathrm{A}-\mathrm{C}^{*} \\
\mathrm{~A}-\mathrm{D} \\
\mathrm{C}^{*}-\mathrm{B} \\
\mathrm{D}-\mathrm{B} \\
\mathrm{C}^{*}-\mathrm{D}\end{array}$ & $\begin{array}{r}6271.0 \\
2566.3 \\
4117.5 \\
3364.2 \\
3721.2 \\
2160.9 \\
2930.9 \\
1558.6 \\
786.5 \\
774.2\end{array}$ & $\begin{array}{r}6280.6 \\
2563.8 \\
4121.7 \\
3353.0 \\
3716.8 \\
2158.9 \\
2927.7 \\
1557.9 \\
789.2 \\
768.7\end{array}$ & $\begin{array}{r}9.6 \\
2.5 \\
4.2 \\
11.2 \\
4.4 \\
2.0 \\
3.2 \\
0.7 \\
2.7 \\
5.5\end{array}$ & \multicolumn{2}{|c|}{$\begin{array}{r}92.16 \\
6.25 \\
17.64 \\
125.44 \\
19.36 \\
4.00 \\
10.24 \\
0.49 \\
7.29 \\
30.25\end{array}$} \\
\hline $\begin{array}{c}\mathrm{A} \\
\mathrm{D} \\
\mathrm{G} \\
\mathrm{G}-\mathrm{D} \\
\mathrm{A}-\mathrm{G} \\
\mathrm{D}-\mathrm{G}\end{array}$ & $\begin{array}{r}6294.4 \\
3368.5 \\
2416.6 \\
2925.3 \\
3895.1 \\
956.8\end{array}$ & $\begin{array}{r}6298.6 \\
3369.9 \\
2411.1 \\
2928.7 \\
3887.5 \\
958.8\end{array}$ & $\begin{array}{c}\text { Total } \ldots . . . \\
4.2 \\
1.4 \\
5.5 \\
3.4 \\
7.6 \\
2.0\end{array}$ & \multicolumn{2}{|c|}{$\begin{array}{r}17.64 \\
1.96 \\
30.25 \\
11.56 \\
57.76 \\
4.00\end{array}$} \\
\hline $\begin{array}{c}\mathrm{A} \\
\mathrm{C} \\
\mathrm{D} \\
\mathrm{A}-\mathrm{C} \\
\mathrm{A}-\mathrm{D} \\
\mathrm{C}-\mathrm{D}\end{array}$ & $\begin{array}{r}6295.7 \\
3981.2 \\
3362.2 \\
2323.6 \\
2942.8 \\
619.7\end{array}$ & $\begin{array}{r}6300.3 \\
3979.1 \\
3359.7 \\
2321.2 \\
2940.6 \\
619.4\end{array}$ & $\begin{array}{c}\text { Total. } \\
\quad 4.6 \\
2.1 \\
2.5 \\
2.4 \\
2.2 \\
0.3\end{array}$ & \multicolumn{2}{|c|}{$\begin{array}{r}21.16 \\
4.41 \\
6.25 \\
5.76 \\
4.84 \\
0.09\end{array}$} \\
\hline & & & Total_.... & \multicolumn{2}{|c|}{42.51} \\
\hline \multirow[b]{2}{*}{ Comparison } & \multirow[b]{2}{*}{$\begin{array}{c}\text { Total of } \\
\text { (Difference) }\end{array}$} & \multirow[b]{2}{*}{$\begin{array}{l}\text { Degrees of } \\
\text { freedom }\end{array}$} & \multirow[b]{2}{*}{ Quotient } & \multicolumn{2}{|c|}{ Standard deviation } \\
\hline & & & & $\begin{array}{c}\text { Single } \\
\text { measure- } \\
\text { ment }\end{array}$ & $\begin{array}{l}\text { Adjusted } \\
\text { value }\end{array}$ \\
\hline 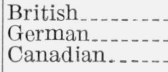 & $\begin{array}{r}313.12 \\
123.17 \\
42.51\end{array}$ & $\begin{array}{l}6 \\
3 \\
3 \\
3\end{array}$ & $\begin{array}{l}52.19 \\
41.08 \\
14.17\end{array}$ & $\begin{array}{l}7.2 \\
6.4 \\
3.8\end{array}$ & $\begin{array}{l}4.5 \\
4.5 \\
2.7\end{array}$ \\
\hline
\end{tabular}

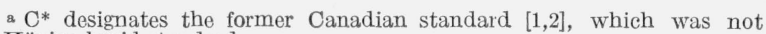
a Hönigschmid standard. 
unusually close agreement, considering the limited number of degrees of freedom available for each estimate. In the course of calibrating another radium preparation against $A$ and $D$ at the Bureau, a fourth estimate of the standard deviation was also found to be $3.8 \mu \mathrm{w}$.

The standard deviation for the adjusted estimates is obtained by dividing the calculated standard deviation shown in table 9 by the square root of $(n+1) / 2$, where $n$ standards have furnished $n(n+1) / 2$ measurements. In the present work, with three standards the divisor is $\sqrt{2}$, and with four standards the divisor is $\sqrt{2.5}$.

\subsection{Electroscope Measurements}

Comparison of two radium standards by the electroscope is best effected by alternating the two standards in a support at a fixed distance from the electroscope and taking the ratio of the times (corrected for background) for the electroscope leaf to fall through a specified angle. Three standards are intercompared by determining the ratios for all three possible pairs of standards, a complete set of readings being taken by each of two operators. These measurements were repeated twice, using two fixed distances from the electroscope for the new Canadian standard, whereas four different distances were used in the work with the German standards. In the earlier work [1] with the British standard and the old Canadian standard, three operators and two distances were used and a complete repetition made, so that 12 measurements were available.

Statistical examination of the results showed them independent of both distance and operator. The standard deviation for any particular ratio was determined from the 8,6 , or 12 individual determinations available. The standard deviations calculated for the various ratios are shown in table 10, both as calculated and when expressed as parts per thousand of the average value for the ratio. The standard deviation for a result obtained by one operator working at one distance is 2.1 parts per thousand. The standard deviation for the average

Table 10. Standard deviations for electroscope measurements

\begin{tabular}{|c|c|c|c|c|}
\hline \multirow{2}{*}{$\begin{array}{c}\text { Radium } \\
\text { standards } \\
\text { compared a }\end{array}$} & \multirow{2}{*}{$\begin{array}{c}\text { A verage } \\
\text { ratio, } \\
\text { unadjusted }\end{array}$} & \multirow{2}{*}{$\begin{array}{c}\text { Number of } \\
\text { measure- } \\
\text { ments b }\end{array}$} & \multicolumn{2}{|c|}{ Standard deviation } \\
\hline & & & Absolute & $\begin{array}{l}\text { Parts per } \\
\text { thousand }\end{array}$ \\
\hline $\begin{array}{l}A / D \\
A / G \\
D / G\end{array}$ & $\begin{array}{l}1.8684 \\
2.6095 \\
1.3936\end{array}$ & $\begin{array}{l}8 \\
8 \\
8\end{array}$ & $\begin{array}{r}0.0043 \\
.0058 \\
.0033\end{array}$ & $\begin{array}{l}2.3 \\
2.2 \\
2.6\end{array}$ \\
\hline $\begin{array}{l}A / D \\
A / C \\
D / C\end{array}$ & $\begin{array}{l}1.8709 \\
1.5771 \\
0.84454\end{array}$ & $\begin{array}{l}6 \\
6 \\
6\end{array}$ & $\begin{array}{l}.0041 \\
.0026 \\
.0013\end{array}$ & $\begin{array}{l}2.2 \\
1.7 \\
1.6\end{array}$ \\
\hline $\begin{array}{l}A / C \\
A / B \\
A / C^{*} \\
B / C^{*} \\
B / D \\
C^{*} / D\end{array}$ & $\begin{array}{l}1.8703 \\
2.4438 \\
1.5675 \\
0.64246 \\
0.76650 \\
1.1918\end{array}$ & $\begin{array}{l}12 \\
12 \\
12 \\
12 \\
12 \\
12\end{array}$ & $\begin{array}{l}.0043 \\
.0083 \\
.0048 \\
.0022 \\
.0024 \\
.0027\end{array}$ & $\begin{array}{l}2.3 \\
3.4 \\
3.1 \\
3.4 \\
3.1 \\
2.3\end{array}$ \\
\hline
\end{tabular}

a $\mathrm{C}^{*}$ designates the former Canadian standard $[1,2]$, which was not a Hönigschmid standard.

b Degrees of freedom equals number of measurements minus 1 . ratio is obtained by dividing by the square root of the number of measurements, giving $0.75,0.85$, and 0.85 parts per thousand as the standard deviation for the average ratios for the German, Canadian, and British studies, respectively.

\section{Best Estimates for the Hönigschmid Standards}

The data tabulated in table 4 have been used to fit straight lines to points that have been plotted using the radiation-balance ratio as ordinate and the weight ratio as abscissa. Only the ratios using $D$ as the denominator are used. The three points plotted for the February 1954 data have the coordinates $(1.869,1.873),(0.7628,0.7648),(1.000,1.000)$. The point $(1.000,1.000)$ establishes a unit scale where one unit is set equal to 20.45 Hönigschmid milligrams. The line is determined by minimizing the sum of the squares of the perpendicular distances from the plotted points to the fitted line. The formulas are given in [2]. A perpendicular from each plotted point to the fitted line determines the coordinates of matching points on the line. The abscissa for each point is then converted back to Hönigschmid milligrams by multiplying by 20.45. The weights corresponding to the points on the line are compared with Hönigschmid's masses in table 11.

TABLE 11. Estimates, in Hönigschmid milligrams, of the masses of the Hönigschmid radium standards as of June 2, 1934

\begin{tabular}{|c|c|c|c|c|c|}
\hline Standard & $A$ & $B$ & $C$ & $D$ & G \\
\hline Hönigschmid's mass _._ & 38.23 & 15.60 & 24.15 & 20.45 & 14. 61 \\
\hline $\begin{array}{l}\text { Mass derived from radiation } \\
\text { balance and Hönigschmid }\end{array}$ & $\left\{\begin{array}{l}38.23_{7} \\
38.24_{2} \\
38.222_{5}\end{array}\right.$ & \begin{tabular}{c}
$15.60_{5}$ \\
\hdashline-
\end{tabular} & 24.154 & $\begin{array}{l}20.43_{1} \\
20.42_{1} \\
20.45_{0}\end{array}$ & 14. $62_{2}$ \\
\hline $\begin{array}{l}\text { Mass derived from electro- } \\
\text { scope and Hönigschmid. }\end{array}$ & $\left\{\begin{array}{r}\text { a } 38.21_{6} \\
38.21_{6} \\
38.22_{3}\end{array}\right.$ & $\begin{array}{r}\text { a15. } 628 \\
-\end{array}$ & 24.177 & $\begin{array}{r}\text { a } 20.44_{2} \\
20.44_{1} \\
20.44_{5}\end{array}$ & 14.633 \\
\hline
\end{tabular}

a These results differ slightly from those given in table 5 of reference [1], the computations having been repeated giving greater weight $(k=1)$ to the electroscope ratios than in that paper $(k=2)$.

Three similar lines were calculated for the ratios obtained with the electroscope. In every instance the derived masses in Hönigschmid milligrams agree with Hönigschmid's masses within his stated weighing errors. In order to be assured that no preference was given to $D$, in taking it as unity in the estimates of the best values, the calculation was run again in the $B A D$ and $G A D$ series, respectively, taking $B$ and $G$, the smallest standards, as unity. No greater differences than 2 or 3 parts in the third decimal place were, however, observed.

It should be emphasized that these derived masses are the best estimates of the values of the Hönigschmid standards so far as the National Bureau of Standards results are concerned. Internationally recommended values must await the correlation of the results from all other laboratories. 
We gratefully acknowledge the courtesy of the President of the National Research Council of Canada and of the President of the PhysikalischTechnische Bundesanstalt of the Federal Republic of Germany for making their respective Hönigschmid radium standards available to us for measurement; and we express our thanks to K. W. Geiger and G. v. Droste, respectively, for bringing the standards personally to Washington, D. C. We also extend grateful acknowledgments to W. E. Perry of the National Physical Laboratory for many helpful discussions and especially for drawing our attention to Hönigschmid's statement that his weights were not compared with the standard kilogram.

We also express our thanks to Mary G. Natrella of the NBS Statistical Engineering Laboratory, for assistance with the computing; and one of us (W. B. M.) is very grateful to M. Waxman, of the NBS Temperature Measurements Section, for his kind advice on the temperature-attenuating enclosure for the radiation balance that was installed some time prior to the investigations here described.

\section{References}

[1] T. I. Davenport, W. B. Mann, C. C. McCraven, and C. C. Smith, J. Research NBS 53, 267 (1954), RP2544 part 1.

[2] W. S. Connor and W. J. Youden, J. Research NBS 53, 273 (1954), RP2544, part 2.

[3] W. S. Michel and G. N. Whyte, Can. J. Phys. 33, 521-523 (1955).

[4] C. Garrett and K. W. Geiger, Can. J. Phys. 34, 1075 (1956)

[5] L. F. Curtiss, Rev. Sci. Instr. 16, 363 (1928).

[6] W. B. Mann, J. Research NBS 52, 177 (1954), RP2486.

[7] W. B. Mann, J. Research NBS 53, 277 (1954), R P2545.

[8] O. Hönigschmid, Anz. Akad. Wiss. Wien 82, 30 (1945).

Washington, May 11, 1956. 